\title{
Assessment of Ethno-Veterinary Management Practices among Sheep and Goat Farmers in Southwest Nigeria
}

\author{
A. O. Adekunmi ${ }^{1}$, A. Ajiboye ${ }^{1}$, A. O. Awoyemi ${ }^{1 *}$, F. O. Osundare ${ }^{1}$, \\ F. M. Oluwatusin ${ }^{1}$, S. O. W. Toluwase ${ }^{1}$ and K. A. Abdu-Raheem ${ }^{1}$ \\ ${ }^{1}$ Department of Agricultural Economics and Extension Services, \\ Ekiti State University, Ado-Ekiti, Nigeria.
}

\begin{abstract}
Authors' contributions
This work was carried out in collaboration among all authors. Author AOA designed the study, performed the statistical analysis, wrote the protocol and wrote the first draft of the manuscript. All other authors reviewed the drafts of the manuscript, managed the analysis and literature searches of the study and helped in the interpretation of the results. All authors read and approved the final manuscript.

Article Information

DOI: 10.9734/ARRB/2020/v35i330199 Editor(s):

(1) Dr. Md. Torequl Islam, Federal University of Piaui, Brazil.

Reviewers:

(1) Philip Asumang, Kwame Nkrumah University of Science and Technology, Ghana. (2) Joseph Atawalna, Kwame Nkrumah University of Science and Technology, Ghana. (3) M. N. Balakrishnan Nair, Trans Disciplinary University, India. Complete Peer review History: http://www.sdiarticle4.com/review-history/56406
\end{abstract}

Original Research Article

Received 22 February 2020 Accepted 28 April 2020 Published 05 May 2020

\section{ABSTRACT}

The study assessed the determinants of the use of Ethno-Veterinary Management (EVM) practices among sheep and goats farmers in southwest, Nigeria. A validated interview schedule was used to source information from one hundred and twenty farmers for the study. Data were collected on selected farmers' socio-economic characteristics, various EVM practices and constraints encountered on the use of various EVM practices. Descriptive statistics such as frequency count, percentage, means, standard deviation and ranking were employed to summarize the data. Binomial logit regression analysis was employed to assess the determinants of the use of EVM practices among sheep and goats farmers. The study revealed that the mean age of the respondents was 32.7 years with $58.3 \%$ males. Also, $91.7 \%$ were able to read and write and the mean household size was 4 while $40 \%$ received information on EVM practices. The common 
diseases and pests of sheep and goats in the study area were foot rot, mastitis, pneumonia, conjunctivitis, trypanosomiasis, ticks, fleas and mites. Common EVM practices employed by the farmers were: the use of spent engine oil, kerosene, oil extracts of palm oil vernonia conferta leaves etc. Age and sex had negative relationships with the use of EVM practices at $5 \%$ level of significance while educational level, household size, farming experience, sources of information on EVM practices had positive significant relationships with the use of EVM practices. Insufficient fund was the major constraint hindering the rearing of sheep and goats in the study area. It was concluded that small ruminants' farmers did manage their stocks employing some EVM practices and sensitize farmers on the efficacy of some EVM practices. Government should encourage veterinary practices which will integrate western medicines and EVM practices together for the use of small ruminants' farmers.

Keywords: Assessment; ethno-veterinary; management; practices; small ruminants.

\section{INTRODUCTION}

Poor animal health is an important factor limiting animal productivity in most developing countries. In developing countries like Nigeria, small-scale farmers generally have poor access to modern medicines to cater for the health of their livestock. This might be due to the poverty status of the farmers themselves, decline in funding for veterinary services and for animal health care in general. For these and other reasons, most of the animals kept by sheep and goat farmers are not reached easily by veterinary personnel. Ethno-veterinary management practices came into play instead of western health care practices Ethno-Veterinary management practices are all about traditional practices. Traditional practices can be used to provide economical solutions to improve productivity of animals and reduction in poverty of the poor farmers [1,2]. The EthnoVeterinary knowledge has been developed through trial and error and grassroots development which. It can play a significant role to empower people by enhancing the use of their own knowledge and resources.

In Nigeria, [3] reported that farmers use traditional remedies because they are more readily available and are cheaper. In the Southwest Nigeria like in other parts of the country, small ruminant's production and productivity is impeded by various constraints which include health. The constraints can sufficiently be alleviated or reduced by western medicines such as vaccination, chemoprophylaxis/chemotherapy, feeding animals with formulated rations and proper housing. Since, small ruminants are in the hands of local farmers in the study area, they are scarcely aware of improved management services. In some cases, many of those who are aware of the services cannot afford to pay for veterinary services because they are expensive.
Hence, the use of Ethno-Veterinary Medicine (EVM), which is the community based or indigenous knowledge for managing livestock are incorporated into farming systems.

In many countries, there has been little documentation of traditional knowledge; rather, it has been transmitted across generations by an oral tradition and therefore is in danger of extinction [4]. In the face of rising cost of Western-style medicine and increased concern about development of drug resistant parasites and residues of chemical veterinary drugs in the animal products, the sustainability of livestock production depend on the indigenous knowledge and practices. A search for the indigenous knowledge and practices for managing livestock is therefore of utmost necessity. The present study was undertaken to assess the EthnoVeterinary management practices among sheep and goat farmers in Southwest, Nigeria. The objectives are as follows:

(i) Describe the socio-economic characteristics of sheep and goats farmers in the study area,

(ii) Identify the various ethno-veterinary management practices utilized in sheep and goats' production in the study area;

(iii) Analyze the management tasks and labour requirements of small ruminants production;

(iv) Identify the various small ruminants' diseases, pests and symptoms commonly found in the study area;

(v) Identify the major constraints hindering effective utilization of ethno-veterinary management practices among the small ruminants' (sheep and goats) farmers.

Hypothesis: There is no significant relationship between socio-economic characteristics of sheep 
and goats farmers and the use of Ethnoveterinary management practices in the study area.

\section{METHODOLOGY}

The study was carried out in southwest Nigeria which covers Lagos, Ogun, Ondo, Osun, Ekiti and Oyo States. The domain is mainly dominated by the Yoruba ethnic group. It has land area of about 114, 271 square kilometers (about 12\% of total land mass of Nigeria), lying between latitude $4^{\circ} 21^{1}$ and $9^{\circ} 23^{1}$ North of the equator and longitude $2^{\circ} 25^{1}$ and $6^{\circ} 3^{1}$ East. The study population comprises of sheep and goats farmers inhabiting rural communities of Southwest, Nigeria. A multi-stage sampling procedure was utilized to select the respondents for the study from the population. At the first stage, three states were purposively selected for the study on the basis of their being contiguous. The states were Osun, Ekiti and Oyo states. The second stage involved the proportionate selection of Local Government Areas (LGAs) based on the number of LGAs in each state selected. Thus, one, two and three LGAs were selected from Ekiti, Osun and Oyo states respectively. At the third stage, two rural communities were randomly selected from each LGA taken for the study. At the final stage, ten small ruminants' farmers were randomly and purposively sampled from each of the rural communities selected for the study. A total of one hundred and twenty small ruminants' farmers were selected for the study. Data collected were analyzed using descriptive statistics such as frequency counts, percentages, mean, standard deviation, charts, ranking. To identify the determinants of the use of EVM practices among the small ruminants' farmers, the farmers' responses of Yes (1) or No (0) responses to the use of EVM practices were regressed on their socio-economic characteristics using binomial logit regression model. The logit regression model is specified below;

$$
\log =\mathrm{P} / \mathrm{R}-\mathrm{P}
$$

Linearizing

$$
\mathrm{Y}=\mathrm{a}+\mathrm{b} 1 \times 1+\mathrm{b} 2 \times 2+b 3 \times 3 \ldots \ldots \ldots . . .66 \times 6+u
$$

Where

$Y$ is the respondents' use of EVM practices. $Y=1$ for users and 0 for non-users. $b 1-b_{6}=$ Regression co-efficient of $\times 1$----------x6 to be estimated

$\mathrm{Xn}=$ Independent or explanatory variables $\mathrm{u}=$ Error term.

\section{RESULTS AND DISCUSSION}

The results in Table 1 reveal that majority $(60.8 \%)$ of farmers rearing small ruminants (sheep and goats) in Southwest, Nigeria. were between the age of 31 and 50 years while only 24.3 per cent of the respondents were between 51 and 60 years with the mean age of 32.7 years. This implies that most of the respondents were in their active and productive age. Also 58.3 percent were males and 41.7 percent were females, indicating that males dominated the rearing of sheep and goats in the study area. Majority $(91.7 \%)$ could read and write, Islamic religion worshippers (45.8\%) dominated the area with Christians constituting 38.5 percent of the respondents and only 15.8 percent were traditional religion worshippers. The results also show that 55.8 percent of the respondents had between 5 and 8 members in their households while 27.3 percent had above 8 members with a mean family size of 4 . Furthermore, majority (55.8\%) of the respondents had farming as their primary occupation, 31.7 percent engaged in petit trading of farm produce such as pepper, yam, cassava, and others while only 10.0 percent were artisans like barbing, shoe making, bricklaying etc. This agrees with the report of [5] which stated that rural dwellers in Nigeria have farming as their major livelihood activity. The results in Table 1 also indicate that about 43.3 percent of the respondents had between 6 and 10 years of rearing sheep and goats while 21.7 percent had between 11 and 15 years, only 1.7 percent of the respondents had up to or less than 5 years of sheep and goats rearing experience. The results also show that majority $(57.5 \%)$ of the respondents relied on personal savings as the major capital source while 24.2 percent relied on friends and relatives for capital source. Only 15.0 percent got money from cooperative societies.

Sources of information as shown in Fig. 1 revealed that 40.0 percent of the respondents received information on Ethno-veterinary management practices from other farmers who are either friends or neighbors, 31.2 percent from cooperative societies while 18.8 percent from Extension agents, Government and NonGovernment agencies. Only 10.0 percent 
received the information from radio, television, and other social media.

The results in Table 2 show various symptoms of the prevailing small ruminants' diseases and pests in the study area. Majority $(70.8 \%)$ of the respondents indicated that they recognized foot rot in the affected animals through lameness, inflammation of the skin, ulceration of the foot as most known symptoms. Majority $(69.2 \%)$ of the respondents also were conversant with the symptoms of pneumonia such as fever, painful cough, dyspnea and anorexia, dullness in their animals. In the same way, 61.7 percent of the respondents identified sore mouth through the symptoms such as scabs or blisters on the lips, nose udder and teats, while botulism was identified through stiffness of muscles, incoordination, abnormal respiration, frequent urination, serious nasal discharges etc. as indicated by 59.2 percent of the respondents.

Table 1. Distribution of farmers rearing small-ruminants according to their socio-economic characteristics

\begin{tabular}{|c|c|c|c|}
\hline Variables & Frequency & Percentage & Central tendencies \\
\hline \multicolumn{4}{|l|}{ Ages (years) } \\
\hline$\leq 30$ & 14 & 11.7 & Mean= \\
\hline $31-40$ & 34 & 28.3 & $32.7 \pm 3.26$ \\
\hline $41-50$ & 39 & 32.5 & \\
\hline $51-60$ & 29 & 24.2 & \\
\hline$>60$ & 04 & 3.3 & \\
\hline \multicolumn{4}{|l|}{ Sex } \\
\hline Male & 70 & 83.3 & \\
\hline Female & 50 & 41.7 & \\
\hline \multicolumn{4}{|l|}{ Educational level } \\
\hline Primary & 36 & 30.0 & \\
\hline Secondary & 59 & 49.2 & \\
\hline Tertiary & 15 & 12.5 & \\
\hline Non-formal & 10 & 8.3 & \\
\hline \multicolumn{4}{|l|}{ Religion } \\
\hline Christianity & 46 & 38.3 & \\
\hline Islam & 55 & 45.8 & \\
\hline Traditional religion & 19 & 15.8 & \\
\hline \multicolumn{4}{|l|}{ Household size } \\
\hline$<5$ & 19 & 15.8 & $4.23 \pm 1.82$ \\
\hline $5-8$ & 67 & 55.8 & \\
\hline$>8$ & 34 & 28.3 & \\
\hline \multicolumn{4}{|c|}{ Years spent in small ruminant rearing } \\
\hline$<5$ & 02 & 1.7 & \\
\hline $6-10$ & 52 & 43.3 & \\
\hline $11-15$ & 26 & 21.7 & \\
\hline $15-20$ & 15 & 12.5 & \\
\hline$>20$ & 05 & 4.2 & \\
\hline \multicolumn{4}{|l|}{ Capital source } \\
\hline Personal savings & 69 & 57.5 & \\
\hline Bank & 4 & 3.3 & \\
\hline Friends and relatives & 29 & 24.2 & \\
\hline Cooperatives & 18 & 15.0 & \\
\hline Farming & 67 & 55.8 & \\
\hline Trading & 38 & 31.7 & \\
\hline Artisans & 12 & 10.0 & \\
\hline Others & 03 & 2.5 & \\
\hline
\end{tabular}




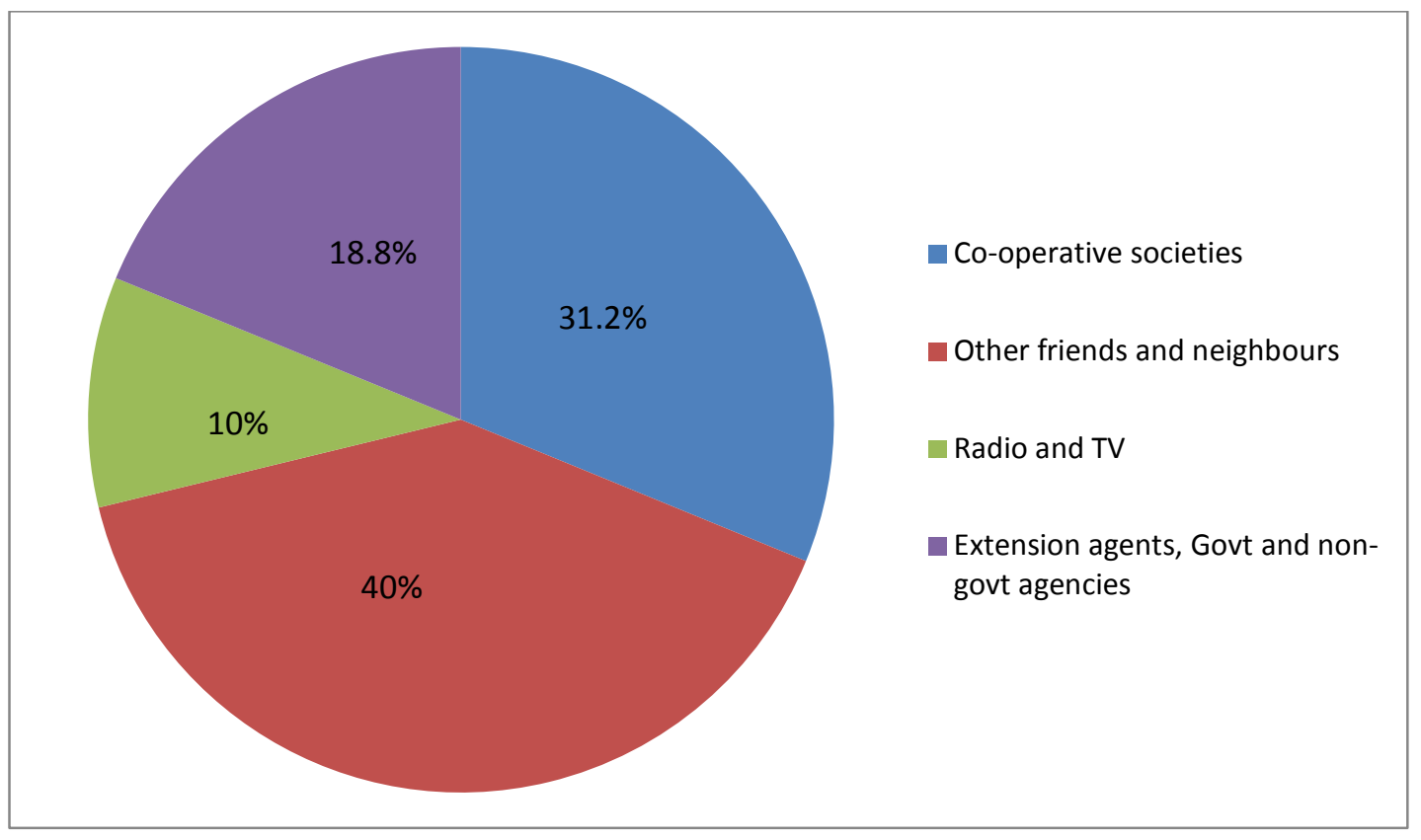

Fig. 1. Sources of information on ethno-veterinary management practices

Others are ringworms (55.8\%) identified through scaly bodies, goat and sheep pox (50.8\%) shown through fever, cutaneous nodular or visceral eruptions, depression, pyrexia, anorexia, laboured breathing and ocular or nasal discharges. About 49.2 percent identified the symptoms of Mastitis through the enlargement of udder, fever, restlessness, abscesses present at different body sections, anorexia, dullness and lethargy, blockage of teat orifices and abscesses. Other common small ruminants diseases and pests are trypanosomiasis $(40.0 \%)$, conjunctivitis $(35.8 \%)$, Ticks $(46.7 \%)$, Fleas $(37.5 \%)$, Mites (26.7\%).

The common Ethno-veterinary management practices and the frequency of usage of these practices are shown in Table 3. The commonly used EVM practices on foot rot in the study area was wood ash with the mean of 3.48, use of spent engine oil $(\bar{x}=3.24)$, use of kerosine $(\bar{x}=3.19)$, oil extracts (palm oil) $(\bar{x}=3.18)$. The disease called ringworm which causes scaly body on the animals are taken care of with the use of engine oil $(\bar{x}=3.40)$ which was ranked $1^{\text {st }}$, the use of cow butter oil $(x=1.73)$. The use of vernonia conferta leaves came $4^{\text {th, }}(\bar{x} 1.23)$; this was not commonly utilized. Removal of the affected animals was the common EVM practice employed on botulism with the mean score of 2.93 and was ranked $1^{\text {st. }}$; followed by the disposal of carcasses of the affected animals $(\mathrm{x}=2.18)$ which came $2^{\text {nd }}$. Common EVM practices on Goat and Sheep pox were destruction of affected flock $(\bar{x}=2.67)$, disinfection of infected premises $(\bar{x}=2.52)$ and fermented ground maize water $(\bar{x}=2.27)$ which were ranked $1^{\text {st }}, 2^{\text {nd }}$ and $3^{\text {rd }}$ respectively. Physical examination of udder $(\bar{x}-$ 3.46 ), massaging the udder with the leaves of spondias monbin $(\bar{x}=2.53)$ were the prominent EVM practices on Mastitis. Maintaining good hygiene $(\bar{x}=3.34)$ and the use of palm kernel oil were the indigenous treatments given to sore mouth. Good nutrition and water $(\bar{x}=3.39)$ and optional sanitation $(\bar{x}=3,23)$ were the common remedies of pneumonia. Mites were being controlled by the use of local soap and lime $(\bar{x}=3.41)$ and the use of engine oil $(\bar{x}=3.30)$. Ticks were removed from small ruminants by the use of fermented ground maize water $(\bar{x}=3.19)$ and the use of kerosine $(\bar{x}=2.85)$ while fleas were being commonly controlled by the use of palm oil $(\bar{x}=3.78)$. The control of mange/scabies were through the use of engine oil $(\bar{x}=3.55)$, palm oil/salt $(\bar{x}=3.26)$ and use of kerosine $(\bar{x}=2.85)$. The results show that sheep and goats farmers harnessed different EVM practices in the study area. This agreed with [6] who submitted that ethno-veterinary medicine differs not only from region to region but also among and within communities.

About 57.5 percent spouses, $25 \%$ farmers themselves, 8.3 per cent spouse and children of 
farmer combined 5.8 per cent farmer and children alone and 3.3 per cent all the family members handle management decisions including marketing or sales of animal products and maintenance of flock structure (Table 4).It is also evident that 70 per cent Spouses of the farmers, 27.5 percent farmers and other family members and 2.5 per farmers were solely

Table 2. List of common diseases and pests in small ruminants' and their observed symptoms with the number and proportion of respondents

\begin{tabular}{|c|c|c|c|}
\hline Diseases/Pests & Symptoms & $\begin{array}{l}\text { Number of } \\
\text { respondents }\end{array}$ & $\begin{array}{l}\text { Proportion or } \\
\text { Percentage }\end{array}$ \\
\hline Foot rot & $\begin{array}{ll}- & \text { Lameness } \\
- & \text { Inflammation of the skin- } \\
\text { horn junction ulceration of } \\
\text { the foot }\end{array}$ & 85 & 70.8 \\
\hline Cough & $\begin{array}{l}\text { Mouth, nose, eyes } \\
\text { discharges, watery } \\
\text { faeces. }\end{array}$ & 36 & 30.0 \\
\hline Ringworms & Scaly body & 67 & 55.8 \\
\hline Botulism & $\begin{array}{ll}\text { - } & \text { Stiffness of muscles } \\
\text { - } & \text { Incoordination } \\
\text { - } & \text { Excitability, flaccid } \\
& \text { paralysis } \\
\text { - } \quad \text { Back aches, salivation, } \\
\text { serious nasal discharges, } \\
\text { frequent urination, } \\
\text { abnormal repiration }\end{array}$ & 71 & 59.2 \\
\hline Goat and sheep pox & $\begin{array}{l}\text { Fever, cutaneous nodular } \\
\text { or visceral eruptions, } \\
\text { dullness, pyrexia, } \\
\text { anorexia laboured } \\
\text { breathing occular or nasal } \\
\text { discharges }\end{array}$ & 61 & 50.8 \\
\hline Mastitis & $\begin{array}{l}\text { Enlargement of udder, } \\
\text { abcesses present at } \\
\text { diferent body sections, } \\
\text { restlessness, anorexia } \\
\text { depression and lethargy, } \\
\text { restlessness, fever, teat } \\
\text { orifices may be blocked, } \\
\text { abscesses. }\end{array}$ & 59 & 49.2 \\
\hline Trypanosomiasis & $\begin{array}{ll}\text { - } & \text { Intermittent fever anaemia } \\
& \text { reduced productivity }\end{array}$ & 48 & 40.0 \\
\hline $\begin{array}{l}\text { Sore mouth } \\
\text { (contagious ecthyma) }\end{array}$ & $\begin{array}{l}\text { Scabs or blisters on the } \\
\text { lips, nose, udder and } \\
\text { teats hoofs, junction and } \\
\text { skin of the low legs }\end{array}$ & 74 & 61.7 \\
\hline Pneumonia & $\begin{array}{l}\text { - Fever, painful cough and } \\
\text { dyspnea, anorexia and } \\
\text { dullness }\end{array}$ & 83 & 69.2 \\
\hline Conjunctivitis & - $\quad$ Stuffy eyes & 43 & 35.8 \\
\hline Mites & $\begin{array}{l}\text { - } \quad \text { Mites seeing moving on } \\
\text { the skin }\end{array}$ & 32 & 26.7 \\
\hline Ticks & Lice on the body & 56 & 46.7 \\
\hline Fleas & $\begin{array}{l}\text { - Loss of hairs and scaly } \\
\text { body }\end{array}$ & 45 & 37.5 \\
\hline
\end{tabular}


Table 3. Distribution of respondents based on frequency of use of ethno veterinary management practices

\begin{tabular}{|c|c|c|c|c|c|c|c|}
\hline $\mathbf{S} / \mathbf{N}$ & $\begin{array}{l}\text { Ethno veterinary management } \\
\text { practices }\end{array}$ & Never & Seldom & Often & $\begin{array}{l}\text { Very } \\
\text { often }\end{array}$ & Mean & Rank \\
\hline \multirow[t]{8}{*}{1} & Foot rot & & & & & & \\
\hline & a. The use of cow butter oil & 39.2 & 40.8 & 20.0 & - & 1.80 & $5^{\text {th }}$ \\
\hline & b. Wood ash & - & 10.0 & 31.7 & 58.3 & 3.48 & $1^{\text {st }}$ \\
\hline & c. Dried bark of Acacia & 66.7 & 24.2 & 9.2 & - & 1.42 & $6^{\text {th }}$ \\
\hline & d. Spent engine oil & - & 11.7 & 52.5 & 35.8 & 3.24 & $2^{\text {nd }}$ \\
\hline & e. Use of kerosene & - & 20.0 & 40.8 & 39.2 & 3.19 & $3^{\text {rd }}$ \\
\hline & f. Oil extracts (palm oil) & - & 15.0 & 51.7 & 33.3 & 3.18 & $4^{\text {th }}$ \\
\hline & g. Sheabutter and salt & 77.5 & 10.0 & 8.3 & 4.2 & 1.39 & $7^{\text {th }}$ \\
\hline \multirow[t]{5}{*}{2.} & Ringworms (Scaly body) & & & & & & \\
\hline & a. Used engine oil & - & 7.5 & 44.2 & 48.3 & 3.40 & $1^{\text {st }}$ \\
\hline & b. Latex extract & 57.5 & 35.8 & 6.7 & - & 1.49 & $3^{\text {rd }}$ \\
\hline & c. Cow butter oil & 60.0 & 15.0 & 16.7 & 8.3 & 1.73 & $2^{\text {nd }}$ \\
\hline & d. Veronia conferta leaves & 80.8 & 15.0 & 4.2 & - & 1.23 & $4^{\text {th }}$ \\
\hline \multirow[t]{4}{*}{3} & Botulism & & & & & & \\
\hline & a. Removal of the affected animal & 6.7 & 22.5 & 31.7 & 34.2 & 2.93 & $1^{\text {st }}$ \\
\hline & b. Correcting the dietary deficiencies & 67.5 & 26.7 & 3.3 & 2.5 & 1.40 & $3^{\text {rd }}$ \\
\hline & c. Disposal of carcasses & 26.7 & 28.3 & 45.0 & - & 2.18 & $2^{\text {nd }}$ \\
\hline \multirow[t]{4}{*}{4} & Goat and sheep pox & & & & & & \\
\hline & $\begin{array}{l}\text { a. Fermented ground maize and milk } \\
\text { flour }\end{array}$ & 1.7 & 46.7 & 40.8 & 2.5 & 2.27 & $3^{\text {rd }}$ \\
\hline & b. Destruction of affected flock & 11.7 & 23.3 & 51.7 & 13.3 & 2.67 & $1^{\text {st }}$ \\
\hline & c. Disinfection of infected premises & 15.0 & 31.7 & 39.2 & 14.2 & 2.52 & $2^{\text {nd }}$ \\
\hline \multirow[t]{4}{*}{5} & Mastitis & & & & & & \\
\hline & $\begin{array}{l}\text { a. Massaging the udder with the } \\
\text { leaves of spondias monbin }\end{array}$ & 14.2 & 26.7 & 50.8 & 8.3 & 2.53 & $2^{\text {nd }}$ \\
\hline & b. Milking hygiene maintenance & 74.2 & 18.3 & 5.0 & 2.5 & 1.35 & $3^{\text {rd }}$ \\
\hline & c. Physical examination of udder & - & 10.0 & 34.2 & 55.8 & 3.46 & $1^{\text {st }}$ \\
\hline \multirow[t]{3}{*}{6} & Sore mouth & & & & & & \\
\hline & a. Use of palm kernel oil & 26.7 & 18.3 & 40.0 & 15.0 & 2.43 & $2^{\text {nd }}$ \\
\hline & b. Maintaining good hygiene & - & 3.3 & 65.8 & 34.2 & 3.34 & $1^{\text {st }}$ \\
\hline \multirow[t]{4}{*}{7} & Pneumonia & & & & & & \\
\hline & $\begin{array}{l}\text { a. Provide optimal sanitation and air } \\
\text { quality }\end{array}$ & - & 19.2 & 38.3 & 42.5 & 3.23 & $2^{\text {nd }}$ \\
\hline & b. Adequate ventilation & - & 15.8 & 52.5 & 31.7 & 3.15 & $3^{\text {rd }}$ \\
\hline & c. Good nutrition and water & - & - & 60.8 & 39.2 & 3.39 & $1^{\text {st }}$ \\
\hline \multirow[t]{4}{*}{8} & Mites(pest) & & & & & & \\
\hline & a. Use of local soap and lime & - & 13.3 & 31.6 & 55.0 & 3.41 & $1^{\text {st }}$ \\
\hline & b. Rub coat with oil & 2.5 & 10.8 & 40.8 & 45.8 & 3.30 & $2^{\text {nd }}$ \\
\hline & $\begin{array}{l}\text { c. Use of palm oil/salt and sulphur } \\
\text { cake }\end{array}$ & - & 10.0 & 52.5 & 37.5 & 3.28 & $3^{\text {rd }}$ \\
\hline \multirow[t]{6}{*}{9} & Ticks & & & & & & \\
\hline & $\begin{array}{l}\text { a. Use of fermented ground maize } \\
\text { water }\end{array}$ & - & 19.2 & 42.5 & 38.3 & 3.19 & $1^{\text {st }}$ \\
\hline & $\begin{array}{l}\text { b. Use of tobacco and bitter leaves } \\
\text { with salt }\end{array}$ & 5.8 & 23.3 & 70.0 & 0.8 & 2.66 & $3^{\text {rd }}$ \\
\hline & $\begin{array}{l}\text { c. Use of tobacco and dongoyaro } \\
\text { leaves }\end{array}$ & 1.7 & 39.2 & 52.5 & 6.6 & 2.64 & $4^{\text {th }}$ \\
\hline & d. Use of kerosene & 13.3 & 15.0 & 44.2 & 27.5 & 2.85 & $2^{\text {nd }}$ \\
\hline & e. Handpicking & 8.3 & 35.8 & 46.7 & 9.2 & 2.57 & $5^{\text {th }}$ \\
\hline
\end{tabular}




\begin{tabular}{llllllll}
\hline S/N & $\begin{array}{l}\text { Ethno veterinary management } \\
\text { practices }\end{array}$ & Never & Seldom & Often & $\begin{array}{l}\text { Very } \\
\text { often }\end{array}$ & Mean & Rank \\
\hline 10 & Fleas & & & & & & \\
\hline & $\begin{array}{l}\text { a. Use of venonia confera leaves } \\
\text { b. Use of palm oil }\end{array}$ & 68.3 & 23.3 & 8.3 & - & 1.40 & $2^{\text {nd }}$ \\
\hline 11 & 1.7 & 3.3 & 10.0 & 85.0 & 3.78 & $1^{\text {st }}$ \\
\hline Mange/scabies & & & & & & \\
\hline & $\begin{array}{l}\text { a. Use of palm oil/salt } \\
\text { b. Use of engine oil }\end{array}$ & 1.7 & 10.0 & 48.3 & 40.0 & 3.26 & $2^{\text {nd }}$ \\
& $\begin{array}{l}\text { c. Use of sulphur cake } \\
\text { d. Use of kerosene }\end{array}$ & 85.0 & 15.0 & - & - & 1.15 & $6^{\text {th }}$ \\
& e. Use of gammalin & 13.3 & 15.0 & 44.1 & 27.5 & 2.85 & $3^{\text {rd }}$ \\
& f. The use of hot oi//limestone & 20.0 & 48.3 & 25.0 & 6.7 & 2.18 & $4^{\text {th }}$ \\
& 50.8 & 40.8 & 6.7 & 1.7 & 1.59 & $5^{\text {th }}$ \\
\hline
\end{tabular}

Table 4. Management tasks and labor requirements of small ruminants' production among rural households

\begin{tabular}{lll}
\hline Task/ category & Frequency & Percentage \\
\hline Marketing and flock structure maintenance & & \\
\hline Small ruminants' farmer & 30 & 25.0 \\
Spouse of the farmer & 69 & 57.5 \\
Family members & 04 & 3.3 \\
Spouse and children alone & 10 & 8.3 \\
Farmer and children alone & 07 & 5.8 \\
\hline Labor for feeding & & \\
\hline Small ruminants farmer & 33 & 27.5 \\
Spouse of the farmers & 84 & 70.0 \\
Rural family members & 03 & 2.5 \\
\hline Labor for sanitation duties & & \\
\hline Small ruminants' family only & 41 & 34.2 \\
Spouse of the farmer & 57 & 47.5 \\
Children of the family members & 22 & 18.3 \\
\hline
\end{tabular}

Source: Field survey, 2018

Multiple responses were given

Table 5. Various constraints encountered by the small ruminants' farmers in the study area

\begin{tabular}{llll}
\hline Constraints & Frequency & Percentage & Ranks \\
\hline Inadequate technical know-how & 75 & 62.5 & $5^{\text {th }}$ \\
Emergence of western veterinary services & 100 & 83.3 & $3^{\text {rd }}$ \\
Inadequate/poor storage techniques & 80 & 66.7 & $4^{\text {th }}$ \\
Shortage of some materials at times & 52 & 43.3 & $6^{\text {th }}$ \\
Difficulties in practice on a large scale & 103 & 85.8 & $2^{\text {nd }}$ \\
Insufficient funds & 109 & 90.8 & $1^{\text {st }}$ \\
\hline
\end{tabular}

responsible for feeding their animal. Sanitationrelated duties were mainly performed by spouses of the farmers $(47.5 \%)$, while 34.2 percent farmers alone performed sanitation-related duties.

Majority of farmers $(90.8 \%)$ indicated insufficient funds as the major constraint for sheep and goat production (Table 5). 85.8 percent indicate that it was difficult to rear sheep and goat on a large scale employing ethno veterinary management practices alone. Other constraints encountered by sheep and goat farmers were emergence of western veterinary services $(83.3 \%)$, this might probably be, because the overwhelming use of western veterinary services could aid ethno veterinary services to go into extinction, poor or inadequate storage facilities and techniques for EVM products are constraints for promotion of EVM.

The result of the logit regression model revealed that age with coefficient value of $(-0.19)$, sex (0.272 ) had significant but negative relationships with the use of EVM practices at $5 \%$ level of probability while educational level (0.308), 
Table 6. The result of the Logit regression model

\begin{tabular}{|c|c|c|c|c|}
\hline Variable & Coefficiencent & Standard error & T-value & P-value \\
\hline Constant & -1.456 & 0.163 & -7.860 & 0.000 \\
\hline Age & -0.019 & -0.024 & -1.506 & $0.076^{* *}$ \\
\hline Sex & -0.272 & 0.120 & -2.271 & $0.001^{* *}$ \\
\hline Educational level & 0.308 & 0.042 & -5.110 & $0.000^{* *}$ \\
\hline Household size & 0.156 & 0.230 & -3.221 & $0.000^{* *}$ \\
\hline Farming experience & 0.586 & 0.130 & 4.187 & $0.000 * *$ \\
\hline Sources of information & 0.309 & 0.032 & 2.311 & $0.001^{* *}$ \\
\hline
\end{tabular}

household size (0.156), farming experience (0.586) and sources of information on EVM practices (0.309) had positive and significant relationships with the use of EVM practices (Table 6). It is therefore concluded that small ruminants farmers' socio-economic characteristics had significant (both positive and negative) relationships with the use of EVM practices. It is also indicated that age with coefficient value of $(-0.019)$, sex $(-0.272)$ had significant but negative relationship with the use of EVM practices at $5 \%$ level of probability, while educational level (0.308), household size (0.156), farming experience (0.586) and sources of information (0.309) had positive and significant relationship with the use of EVM.

\section{CONCLUSION AND RECOMMENDA- TIONS}

It was revealed from the study that small ruminants' farmers did manage their stocks using some traditional management practices. Commonly used was wood ash, engine oil, culling of affected animals of any disease, maintaining good engine, use of fermented ground maize water. Among others male household heads and male children played major roles in managing their herds. The common diseases of sheep and goats in the study area were ringworms, foot rot, goat and sheep pox, botulism, sore mouth and common pests were ticks, fleas and mites. The major constraints of small ruminants' farmers were insufficient funds, difficulty in putting EVM practices on a large scale.

It is therefore recommended that;

$>$ Integration of Western medicines and Ethno-Veterinary Medicines can be enhanced through formulation of policies which will sustain it.

$>$ Also scientific standardization of EVM practices will enhance their acceptance across the globe. Hence, the need to encourage researchers and users of EVM practices through grants, soft loans, and subsidy to enable them to improve on the existing practices.

\section{CONSENT}

As per international standard written participant consent has been collected and preserved by the authors.

\section{COMPETING INTERESTS}

Authors have declared that no competing interests exist.

\section{REFERENCES}

1. Igbal ZA, Jabban MS, Akhtar G. Muhammed, Lateef $M$. Possible role of ethno-veterinary in poverty reduction in Pakistan: Use of botanical anthelmintics an example, Journal of Agriculture and Social Sciences. 2005;1(2):187-195.

2. Soji Eze T. Nigeria falls to tap $\$ 100$ billion medical plant fund, tribune Nigeria; 2012.

Available:http://www.tribune.com.ngl

(Retrieved 2012-08-28)

3. Chah JM, Igbokwe EM, Chah KF. EthnoVeterinary Medicine used in small ruminant health in the Eastern Guinea Savanna, Nigeria. Livest Res.Rural Dell. 2009;21(12):1-45

4. Matekaire T, Bwakura TM. Ethnoveterinary medicine. A potential alternative to orthodox animal health delivery in 
Zimbabwe. International Journal of Applied Research in Veterinary Medicine. 2004;2(4):269-273.

Available:http://jarvm.com/articles/vo/12lss 4/matekaire JARVM vol12 No4

5. Ekong EE. Rural sociology: An introduction and Analysis of Rural Nigeria; 2010.

6. Wanzala W, Zessin KH, Baumann MPO, Mathias E, Hassanali A. Ethno- veterinary medicine: A critical review of its evolution, perception, understanding and the way forward. Livestock research for Rural Development. 2005; 17(11).

(Retreived July 20, 2008)

Available:http//www.cipav.org.co//rrd17/II/w anz17119.htm

(c) 2020 Adekunmi et al.; This is an Open Access article distributed under the terms of the Creative Commons Attribution License (http://creativecommons.org/licenses/by/4.0), which permits unrestricted use, distribution, and reproduction in any medium, provided the original work is properly cited.

Peer-review history:

The peer review history for this paper can be accessed here: http://www. sdiarticle4.com/review-history/56406 